\title{
Serology- and PCR-based cumulative incidence of SARS-CoV-2 infection in adults in a successfully contained early hotspot (CoMoLo study), Germany, May to June 2020
}

Claudia Santos-Hövener ${ }^{1,2}$, Hannelore K Neuhauser ${ }^{1,2}$, Angelika Schaffrath Rosario ${ }^{1}$, Markus Busch ${ }^{1}$, Martin Schlaud1 , Robert Hoffmann ${ }^{1}$, Antje Gößwald ${ }^{1}$, Carmen Koschollek ${ }^{1}$, Jens Hoebel ${ }^{1}$, Jennifer Allen ${ }^{1}$, Antje Haack-Erdmann ${ }^{3}$, Stefan Brockmann ${ }^{4}$, Thomas Ziese ${ }^{1}$, Andreas Nitsche ${ }^{1}$, Janine Michel ${ }^{1}$, Sebastian Haller ${ }^{1}$, Hendrik Wilking ${ }^{1}$, Osamah Hamouda ${ }^{1}$, Victor M Corman ${ }^{5,6}$, Christian Drosten ${ }^{5,6}$, Lars Schaade ${ }^{1}$, Lothar H Wieler ${ }^{1}$, CoMoLo Study Group ${ }^{7}$, Thomas Lampert ${ }^{1}$

1. Robert Koch Institute, Berlin, Germany

2. These authors contributed equally

3. Landratsamt Hohenlohekreis, Gesundheitsamt, Künzelsau, Germany

4. Department of Health Protection and Epidemiology, Baden-Wuerttemberg State Health Office, Stuttgart, Germany

5. National Consultant Laboratory for Coronaviruses, Berlin Institute of Virology, Charité - Universitätsmedizin, Berlin, Germany

6. German Centre for Infection Research (DZIF), Berlin, Germany

7. The members of the group are listed under Investigators

Correspondence: Hannelore K. Neuhauser (neuhauserh@rki.de)

Investigators: CoMoLo Study Group: Stefan Albrecht, Sabine Born, Hans Butschalowsky, Nina Buttmann-Schweiger, Stefan Damerow, Ute Ellert, Julia Fiebig, Andrea Franke, Julian Gräf, Jasmin Gundlach, Isabell Hey, Sebastian Hinck, Marcel Hintze, Heike Hölling, Robin Houben, Antje Hüther, Melanie Krugmann, Ulrike Kubisch, Ronny Kuhnert, Tim A. Kuttig, Michael Lange, Stefan Meisegeier, Stephan Müters, Ruth Offergeld, Hanna Perlitz, Christina Poethko-Müller, Ute Pöplow do Rego, Franziska Prütz, Anna Sandoni, Giselle Sarganas, Gina Schöne, Silke Stahlberg, Julia Strandmark, Roma Thamm, Felicitas Vogelgesang, Benjamin Wachtler, Jörg Wernitz, Matthias Wetzstein, Christin Wolff

Citation style for this article:

Santos-Hövener Claudia, Neuhauser Hannelore K, Rosario Angelika Schaffrath, Busch Markus, Schlaud Martin, Hoffmann Robert, Gößwald Antje, Koschollek

Carmen, Hoebel Jens, Allen Jennifer, Haack-Erdmann Antje, Brockmann Stefan, Ziese Thomas, Nitsche Andreas, Michel Janine, Haller Sebastian, Wilking Hendrik, Hamouda Osamah, Corman Victor M, Drosten Christian, Schaade Lars, Wieler Lothar H, CoMoLo Study Group, Lampert Thomas. Serology-and PCR-based cumulative incidence of SARS-CoV-2 infection in adults in a successfully contained early hotspot (CoMoLo study), Germany, May to June 2020. Euro Surveill. 2020;25(47): $\mathrm{pii}=2001752$. https://doi.org/10.2807/1560-7917.ES.2020.25.47.2001752

Three months after a coronavirus disease (COVID-19) outbreak in Kupferzell, Germany, a population-based study $(n=2,203)$ found no RT-PCR-positives. IgG-ELISA seropositivity with positive virus neutralisation tests was $7.7 \%$ (95\% confidence interval $(\mathrm{Cl}): 6.5-9.1)$ and $4.3 \%$ with negative neutralisation tests. We estimate $12.0 \%$ (95\% Cl: $10.4-14.0 \%$ ) infected adults (24.5\% asymptomatic), six times more than notified. Full hotspot containment confirms the effectiveness of prompt protection measures. However, $88 \%$ naïve adults are still at high COVID-19 risk.

After a large church concert on 1 March 2020 and a first detected infection with severe acute respiratory syndrome coronavirus 2 (SARS-CoV-2) on 9 March, the southern German community of Kupferzell in the federal state Baden-Württemberg faced a steep increase of SARS-CoV-2 infections. Investigations of the local health authorities showed increasing evidence of community spreading in a complex and chronologically dense pattern of travel returnees who attended a choir and trombone church concert. Wide-reaching infection prevention and local control measures were implemented starting in the week of the first case detection, followed by additional measures such as a ban on gatherings in the federal state starting mid-March. The number of SARS-CoV-2 infections peaked in March but waned in April, and there were only three cases in May (Figure). There were three deaths, aged 59, 81 and 91 years. The cumulative incidence of 1,760 per 100,000 in Kupferzell by the end of April was, at the time of the study, one of the highest in Germany. The Robert Koch Institute (RKI) set out to analyse the SARS-CoV-2 seroprevalence in a random sample of this community from 20 May to 9 June.

\section{CoMoLo study}

The seroepidemiological study in Kupferzell, Germany is part of the population-based corona-monitoring local (CoMoLo) study that investigates the prevalence of SARS-CoV-2 IgG antibodies and of current infections in four communities with a high case incidence. Details are provided in the study protocol [1].

A random sample of 3,534 Kupferzell residents aged 18 years and older from the mandatory population registry (68.9\% of the 5,128 adult residents) was invited to take part in the study, and 2,203; (48.5\% women; 18-94 years; Table 1) had venous blood sampling (Figure). These participants were $63 \%$ of those eligible. Some 2,184 had SARS-CoV-2 RT-PCR testing of throat swabs targeting the $E$ gene and the orf1ab region of SARSCoV-2 [2]. The Robert Koch Institute performed SARSCoV-2-S1 IgG-ELISA (Euroimmun, Lübeck, Germany) 
Notified COVID-19 cases in adults 18 years and older and flow-chart of study design, Kupferzell, Germany, March-June $2020(\mathrm{n}=5,128)$

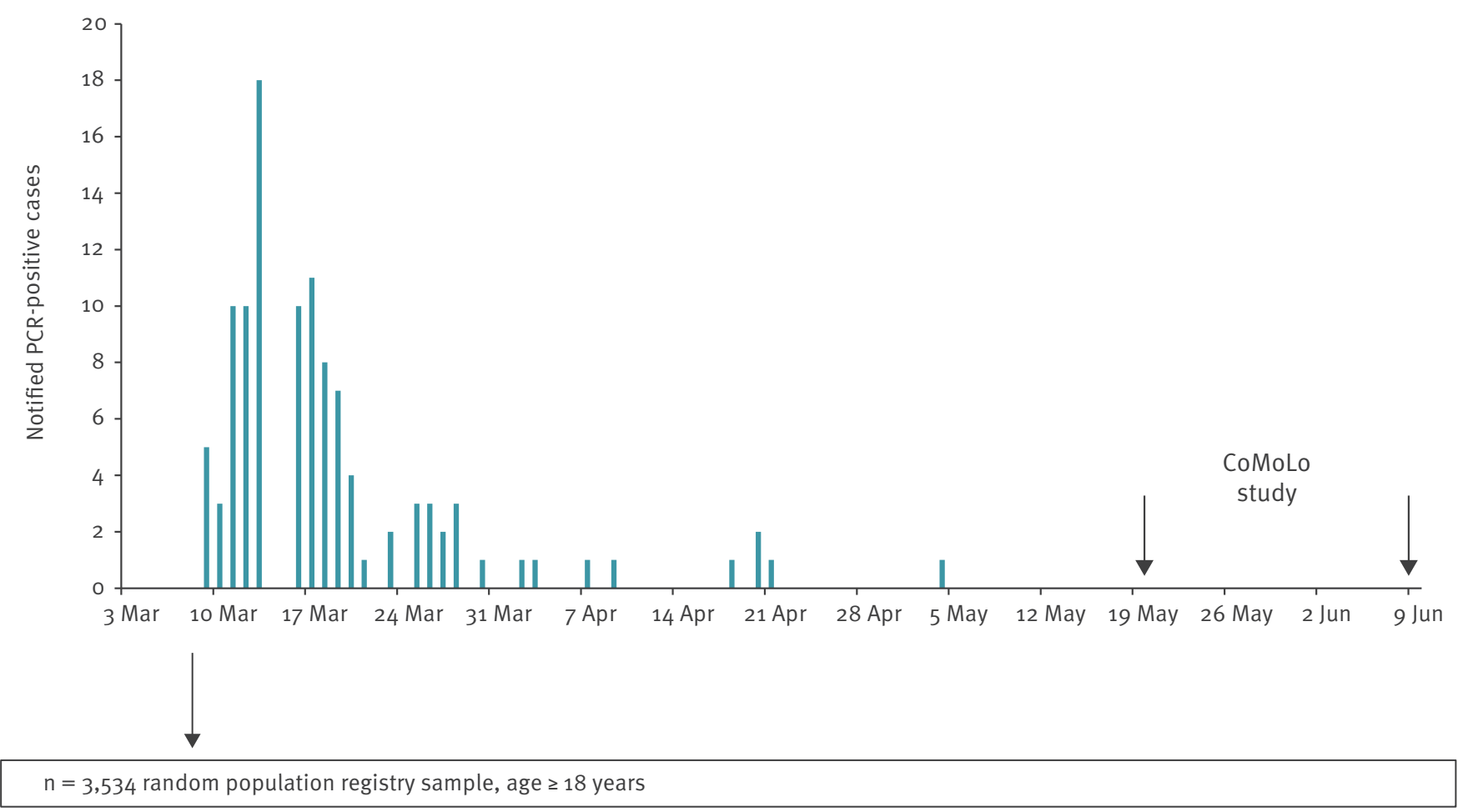

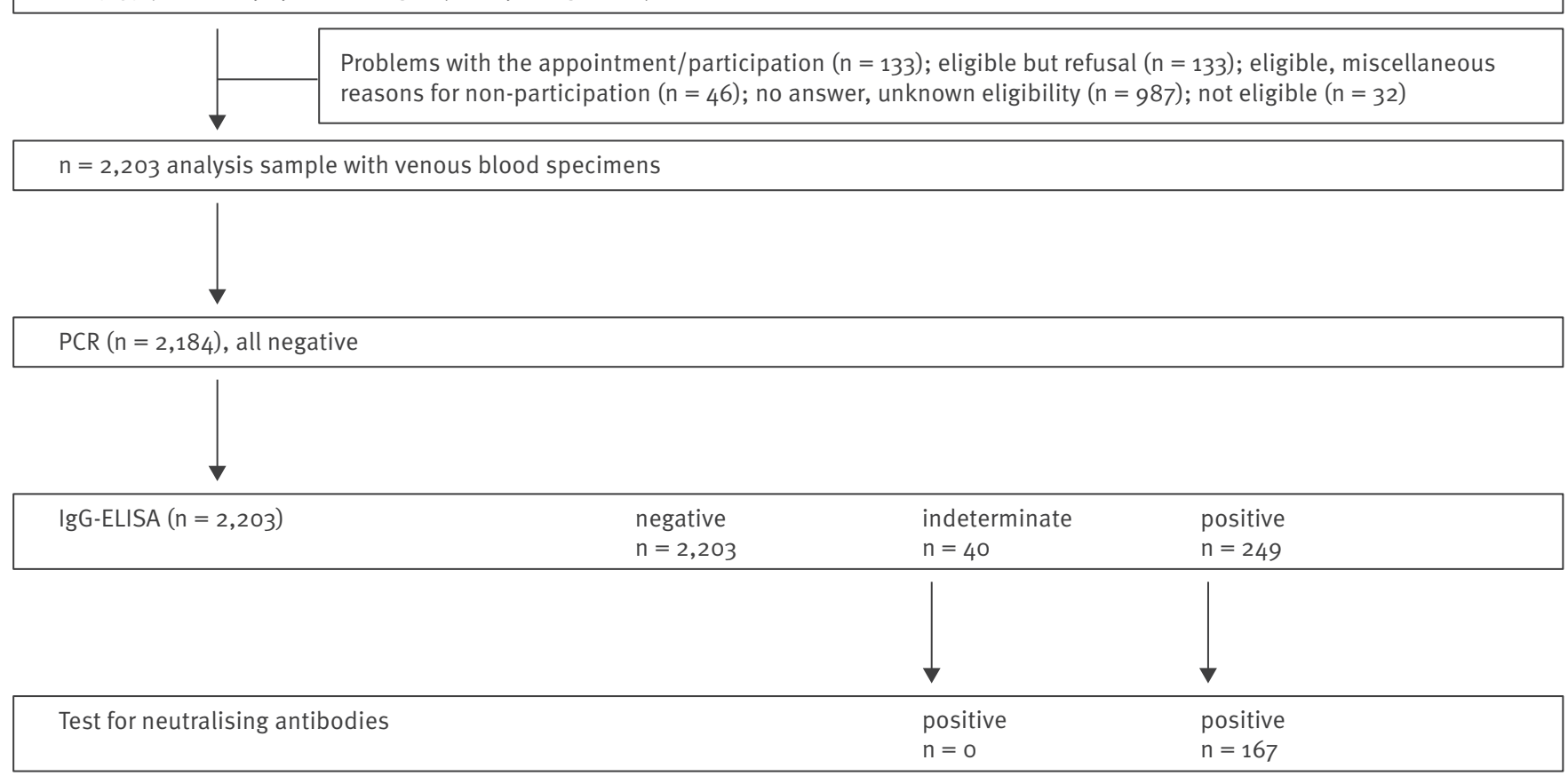

COVID-19: coronavirus disease; 
TABLE 1

Characteristics of study population, COVID-19 cases 18 years and older, Kupferzell, Germany, 20 May-9 June 2020 $(\mathrm{n}=2,203)$

\begin{tabular}{|c|c|c|c|}
\hline & $\mathrm{n}$ & Weighted $\%$ & $95 \% \mathrm{Cl}$ \\
\hline \multicolumn{4}{|l|}{ Sex } \\
\hline Female & 1,143 & 48.5 & $46.6-50.3$ \\
\hline Male & 1,060 & 51.5 & $49.7-53.4$ \\
\hline \multicolumn{4}{|l|}{ Age female } \\
\hline $18-34$ years & 379 & 25.1 & $22.8-27.7$ \\
\hline $35-49$ years & 279 & 23.6 & $21.2-26.3$ \\
\hline $50-64$ years & 282 & 28.5 & $25.8-31.4$ \\
\hline$\geq 65$ & 203 & 22.7 & $20.1-25.5$ \\
\hline \multicolumn{4}{|l|}{ Age male } \\
\hline $18-34$ years & 334 & 26.6 & $23.8-29.6$ \\
\hline $35-49$ years & 254 & 26.2 & $23.3-29.3$ \\
\hline $50-64$ years & 290 & 28.2 & $25.6-31.1$ \\
\hline$\geq 65$ & 182 & 18.9 & $16.5-21.6$ \\
\hline \multicolumn{4}{|l|}{ Secondary school education } \\
\hline Lower & 670 & 42.8 & $40.3-45.3$ \\
\hline Middle & 731 & 28.2 & $26.4-30.1$ \\
\hline Higher & 744 & 29.0 & $26.9-31.1$ \\
\hline \multicolumn{4}{|l|}{ Household size } \\
\hline 1 person & 227 & 11.4 & $10.0-13.0$ \\
\hline 2 persons & 729 & $34 \cdot 3$ & $31.7-36.9$ \\
\hline 3-4 persons & 877 & 39.0 & $36.3-41.8$ \\
\hline$>4$ persons & 324 & $15 \cdot 3$ & $13.2-17.8$ \\
\hline \multicolumn{4}{|l|}{ Exposures } \\
\hline Working with patients & 204 & 10.0 & $8.6-11.5$ \\
\hline Working with customers & 432 & 21.3 & $19.3-23.3$ \\
\hline Travelled abroad since 1 January & 361 & 15.0 & $13.4-16.9$ \\
\hline Participated in event with $\geq 50$ persons & 636 & 26.4 & $24 \cdot 3-28.6$ \\
\hline \multicolumn{4}{|l|}{ Quarantine or isolation } \\
\hline Voluntary & 256 & 11.8 & $10.3-13.4$ \\
\hline Mandated & 317 & $14 \cdot 3$ & $12.6-16.2$ \\
\hline \multicolumn{4}{|l|}{ Self-reported health } \\
\hline Very good & 739 & 31.6 & $29.5-33.7$ \\
\hline Good & 1,156 & 55.2 & $52.9-57.4$ \\
\hline Moderate/bad/very bad & 247 & 13.2 & $11.7-14.9$ \\
\hline \multicolumn{4}{|l|}{ Medical conditions } \\
\hline Self-reported COVID-19 & 50 & 2.4 & $1.8-3.2$ \\
\hline Chronic conditions $^{\mathrm{a}}$ & 638 & 35.3 & $33.0-37.7$ \\
\hline \multicolumn{4}{|l|}{\begin{tabular}{|l|} 
Symptoms since 1 February \\
\end{tabular}} \\
\hline Fever $\geq 38^{\circ} \mathrm{C}$ & 209 & 9.6 & $8.3-11.1$ \\
\hline Dyspnoea, shortness of breath & 145 & 6.6 & $5.6-7.9$ \\
\hline Pneumonia & 11 & 0.5 & $0.3-1.0$ \\
\hline Congested/running nose & 627 & 28.6 & $26.5-30.8$ \\
\hline Cough & 549 & 25.0 & $23.0-27.1$ \\
\hline Pain when breathing & 76 & 3.5 & $2.7-4.4$ \\
\hline Sore throat & 558 & 24.0 & $22.1-26.0$ \\
\hline Loss of smell or taste & 131 & 6.0 & $5.0-7.2$ \\
\hline No symptoms & 1,042 & 51.2 & $48.8-53.7$ \\
\hline Mild symptoms only & 922 & 41.8 & $39.4-44.2$ \\
\hline Moderate or severe symptoms (pneumonia, dyspnoea) & 153 & 7.0 & $5.9-8.3$ \\
\hline
\end{tabular}

$\mathrm{Cl}$ : confidence interval; COVID-19: coronavirus disease.

a Lung or heart disease, diabetes, stroke, hypertension, immunodeficiency.

Complementary categories are not always shown, e.g. 'not working with patients' and missing values are not shown, therefore n do not always add up to the total. 
and applied the thresholds provided in the manual [1]. All samples that tested SARS-CoV-2-S1-IgG-positive (ratio $\geq 1.1$ ) or indeterminate (ratio $\geq 0.8$ to $<1.1$ ) were additionally tested for neutralising antibodies with plaque reduction neutralisation tests (prNT) [3] at the German consultant laboratory for human coronaviruses at Charité - Universitätsmedizin Berlin.

Underascertainment of SARS-CoV-2 infections was calculated as the ratio of two population proportions: the proportion of SARS-CoV-2 infections calculated from our study and the cumulative incidence of nonfatal PCR-positive cases in the adult population of Kupferzell calculated from notified cases aged 18 years and older. Proportions of IgG-positives were adjusted for sensitivity (88.3\%) and specificity (99.2\%) of the Euroimmun S1-SARS-CoV-2 IgG test [4], according to validity studies conducted by the Paul Ehrlich Institute. These validity studies had tested 513 pre-pandemic specimens and 222 convalescent coronavirus disease (COVID-19) patients, the vast majority (96\%) at least 21 days after symptom onset (personal communication, H. Scheiblauer, 30 Sep 2020).

Statistical analyses were conducted using SAS 9.4 survey procedures. Results were weighted to the population of Kupferzell with regard to age group, sex and school education (district level). Clustering within households was taken into account.

\section{Ethical statement}

This study was approved by the ethics committee of the Berlin Chamber of Physicians (Berliner Ärztekammer, reference number Eth-11/20), and the data commissioner of the Robert Koch Institute. All participants gave informed consent.

\section{Seroprevalence}

All SARS-CoV-2 swabs taken during the study were negative in RT-PCR. The population-weighted prevalence of indeterminate IgG results was $1.9 \%$; positive IgG results occurred with a prevalence of $11.3 \%$ or, when corrected for test performance, $12.0 \%$ (95\% confidence interval (Cl): 10.4-14.0) (Table 2). The lowest IgG seroprevalence in women was among the 18-34 year-olds, in men among the 35-49 year-olds. Factors associated with seropositivity were loss of smell or taste, fever $\geq 38^{\circ} \mathrm{C}$, a history of travelling or attending a large event and very good self-reported health. The association of seropositivity with 'quarantine or isolation' is not surprising since these participants were likely to be either diagnosed COVID-19 cases or close contacts. None of the participants with indeterminate IgG had a positive prNT, i.e. neutralising antibodies. The population-weighted seroprevalence of anti-SARS-CoV-2 IgG with positive prNT was $7.7 \%(95 \% \mathrm{Cl}: 6.5-9.1)$.

\section{Cumulative incidence of SARS-CoV-2 infections}

For the cumulative incidence of SARS-CoV-2 infections, we considered current infections (in this study none because all study PCR tests were negative) and past infections. The vast majority of past infections can be identified by IgG antibodies, but not all [5]: in the subgroup of 50 participants with self-reported COVID19 diagnosis done before the study period, only $89 \%$ (weighted percentage; $95 \% \mathrm{Cl}: 77.3-95.0$ ) were IgGpositive (Table 3 ). The seropositivity rate in the 26 participants with self-reported COVID-19 diagnosis with mild symptoms was $87 \%$ (weighted percentage; $95 \%$ $\mathrm{Cl}$ : 70.7-95.1) and in those with moderate-to-severe symptoms $(n=16)$ it was $94 \%$ (weighted percentage; $95 \% \mathrm{Cl}: 66.5-99 \cdot 3)$. However, this was well taken into account by the mathematical correction for sensitivity and specificity since the corrected proportion of seropositives among these 50 participants was ca $100 \%$. $24.5 \%$ of seropositive participants reported that they had not had any of the eight investigated symptoms since 1 February (16.8\% of those with neutralising antibodies).

The underascertainment ratio comparing IgG seropositivity corrected for test performance, with the officially reported cumulative incidence was 6.1 (95\% Cl: $5.2-$ 7.0). If calculated based on seropositivity of both IgG and prNT, the underascertainment ratio would be 3.9 (95\% Cl: 3.2-4.6).

\section{Discussion}

Seroepidemiological studies are key to understanding the distribution of infections in the population, despite uncertainties deriving from test performance and from the proportion of infected persons who never develop or have declining levels of antibodies [5-10].

Our results of $12 \%$ IgG-seropositive participants corrected for test performance and a proportion of $25 \%$ asymptomatic infections are in line with the results from the German high-prevalence towns Gangelt [10] and Neustadt am Rennsteig [11]. Seroepidemiological studies conducted in Germany [12] are systematically tracked by the German national public health institute (Robert Koch Insitute; www.rki.de/covid-19-serostudies-germany). The cumulative incidence of infections of $15.5 \%$ in Gangelt [13] was based on RT-PCR-positive cases and on positive or indeterminate S1-ELISAEuroimmun IgG tests, corrected for the manufacturerprovided sensitivity of $90.9 \%$ and specificity of $99.1 \%$. From Neustadt am Rennsteig [11], a seroprevalence of $8.4 \%$ was reported, based on two of six different IgG immunoassays. Testing of a pre-existing populationbased cohort in the low-prevalence area of Bonn yielded a seroprevalence of ca $1 \%$, based on positive S1-ELISAEuroimmun IgG tests and $0.36 \%$ with both S1-ELISA-IgG and neutralising antibodies [14]. Compared with other European areas with high COVID-19 prevalence such as Ischgl in Austria [15] or the Lodi Red Zone in Lombardy, Italy, [16] the seroprevalence in Kupferzell was still low.

The increased odds of infection after travelling abroad and after participating in larger events are in line with the outbreak history in Kupferzell. From our study and 


\section{TABLE 2A}

Prevalence of SARS-CoV-2 IgG and neutralising antibodies in adults and association with sociodemographic, exposure and clinical characteristics, Kupferzell, Germany, 20 May-9 June 2020 (n=2,203)

\begin{tabular}{|c|c|c|c|c|c|c|c|c|c|c|c|}
\hline & \multicolumn{3}{|c|}{$\begin{array}{l}\text { Prevalence of positive } \\
\text { results in both IgG-ELISA } \\
\text { (ratio } \geq 1.1) \text { and } \\
\text { prNT }\end{array}$} & \multicolumn{2}{|c|}{$\begin{array}{c}\text { IgG-ELISA-positive } \\
(\text { ratio } \geq 1.1)\end{array}$} & \multicolumn{2}{|c|}{$\begin{array}{c}\text { Seroprevalence: } \\
\text { prevalence of IgG } \\
\text { ratio } \geq 1.1 \\
\text { corrected for sensitivity } \\
88.3 \% \text { and specificity } \\
99.2 \%\end{array}$} & \multicolumn{2}{|c|}{$\begin{array}{l}\text { OR for being } \\
\text { IgG-seropositive } \\
\text { adjusted for age } \\
\text { group and sex }\end{array}$} & \multicolumn{2}{|c|}{$\begin{array}{l}\text { Distribution among } \\
\text { seropositives }^{\mathrm{a}} \\
\text { (IgG-ELISA; } \mathrm{n}=249 \text { ) }\end{array}$} \\
\hline & $n$ & $\begin{array}{l}\text { Weighted } \\
\%\end{array}$ & $95 \% \mathrm{Cl}$ & $n$ & $\begin{array}{l}\text { Prevalence, } \\
\text { weighted \% }\end{array}$ & $\begin{array}{c}\text { Weighted } \\
\%\end{array}$ & $95 \% \mathrm{Cl}$ & OR & $95 \% \mathrm{Cl}$ & $\begin{array}{l}\text { Weighted } \\
\%\end{array}$ & $95 \% \mathrm{Cl}$ \\
\hline Total & 167 & 7.7 & $6.5-9.1$ & 249 & 11.3 & 12.0 & $10.4-14.0$ & \multicolumn{2}{|r|}{$\mathrm{Nd}$} & \multicolumn{2}{|c|}{$\mathrm{Nd}$} \\
\hline Female & 96 & 8.7 & $7.1-10.7$ & 136 & 12.2 & 13.0 & $10.8-15.6$ & 1 & Reference & 52.1 & $46.1-58.1$ \\
\hline Male & 71 & 6.7 & $5.2-8.5$ & 113 & 10.5 & 11.1 & $9.0-13.6$ & 0.86 & $0.67-1.12$ & 47.9 & $41.9-53.9$ \\
\hline \multicolumn{12}{|l|}{ Age female } \\
\hline $18-34$ years & 23 & 5.4 & $3 \cdot 5-8.1$ & 31 & 7.5 & $7 \cdot 7$ & $5.1-11.3$ & 1 & Reference & $15 \cdot 5$ & $10.8-21.7$ \\
\hline $35-49$ years & 20 & 7.2 & $4.6-11.1$ & 39 & $14 \cdot 3$ & $15 \cdot 4$ & $11.0-21.0$ & 2.04 & $1.21-3.44$ & 27.6 & $20.6-36.0$ \\
\hline $50-64$ years & 30 & 10.3 & $7 \cdot 3-14 \cdot 4$ & 39 & 13.4 & $14 \cdot 4$ & $10.4-19.5$ & 1.90 & $1.16-3.12$ & 31.3 & $23.8-39.9$ \\
\hline$\geq 65$ & 23 & 12.0 & $8.1-17.5$ & 27 & 13.7 & 14.8 & $10.0-21.2$ & 1.95 & $1.12-3.42$ & 25.5 & $18.2-34.5$ \\
\hline \multicolumn{12}{|l|}{ Age male } \\
\hline $18-34$ years & 25 & 7.2 & $4.7-10.8$ & 40 & 11.3 & 12.0 & $8.2-17.1$ & 1 & Reference & 28.6 & $20.7-38.1$ \\
\hline $35-49$ years & 6 & 2.4 & $1.0-5 \cdot 3$ & 11 & $4 \cdot 5$ & $4 \cdot 3$ & $1.9-8.4$ & 0.37 & $0.18-0.78$ & 11.2 & $6.2-19.6$ \\
\hline $50-64$ years & 23 & 8.1 & $5.4-12.0$ & 37 & 12.9 & 13.9 & $9.9-19.0$ & 1.16 & $0.70-1.93$ & $34 \cdot 7$ & $26.2-44.3$ \\
\hline$\geq 65$ & 17 & 9.8 & $6.1-15 \cdot 3$ & 25 & 14.2 & $15 \cdot 3$ & $10.2-22.3$ & 1.30 & $0.73-2.32$ & $25 \cdot 5$ & $17.6-35.4$ \\
\hline \multicolumn{12}{|c|}{ Secondary school education } \\
\hline Lower & 61 & 9.0 & $6.7-11.8$ & 82 & 11.6 & 12.3 & $9 \cdot 7-15 \cdot 5$ & 0.92 & $0.62-1.35$ & $43 \cdot 3$ & $36.5-50.3$ \\
\hline Middle & 58 & 8.4 & $6.2-11.2$ & 86 & 12.2 & 13.0 & $10.3-16.3$ & 1.10 & $0.78-1.55$ & 30.0 & $24.5-36.1$ \\
\hline Higher & 46 & 6.0 & $4.2-8.6$ & 78 & 10.6 & 11.2 & $8.6-14.4$ & 1 & Reference & 26.8 & $21.5-32.8$ \\
\hline \multicolumn{12}{|l|}{ Household size } \\
\hline 1 person & 14 & 6.8 & $4.0-11.3$ & 21 & 9.6 & 10.1 & $6.2-15 \cdot 7$ & 0.79 & $0.46-1.37$ & 9.6 & $6.2-14.5$ \\
\hline 2 persons & 57 & 8.0 & $6.0-10.6$ & 82 & 11.5 & 12.2 & $9 \cdot 5^{-15 \cdot 5}$ & 1 & Reference & $34 \cdot 5$ & $27.9-41.8$ \\
\hline 3-4 persons & 71 & 8.3 & $6.4-10.7$ & 106 & 12.1 & 12.9 & $10.2-16.2$ & 1.29 & $0.90-1.84$ & 41.5 & $34.4-48.9$ \\
\hline$>4$ persons & 23 & 6.2 & $3.7-10.2$ & 37 & 10.7 & 11.4 & $7.1-17.4$ & 1.13 & $0.67-1.90$ & $14 \cdot 4$ & $9.5-21.2$ \\
\hline \multicolumn{12}{|l|}{ Exposures } \\
\hline $\begin{array}{l}\text { Working with } \\
\text { patients }\end{array}$ & 23 & 12.0 & $8.0-17.6$ & 30 & $14 \cdot 9$ & 16.1 & $10.9-23.0$ & 1.41 & $0.90-2.22$ & $13 \cdot 3$ & $9.3-18.8$ \\
\hline $\begin{array}{l}\text { Working with } \\
\text { customers }\end{array}$ & 31 & $7 \cdot 7$ & $5.2-11.1$ & 48 & 11.9 & 12.7 & $9.2-17.2$ & 1.16 & $0.79-1.71$ & 22.7 & $17.1-29.5$ \\
\hline $\begin{array}{l}\text { Travelled abroad } \\
\text { since } 1 \text { January }\end{array}$ & 31 & 8.9 & $5.8-13.5$ & 58 & 16.7 & 18.1 & $13 \cdot 3-24 \cdot 2$ & 1.93 & $1.31-2.83$ & 21.9 & $16.4-28.7$ \\
\hline $\begin{array}{l}\text { Event with } \geq 50 \\
\text { persons }\end{array}$ & 68 & 11.9 & $9 \cdot 3-15 \cdot 2$ & 102 & 17.2 & 18.8 & $15.0-23.1$ & 2.24 & $1.63-3.07$ & 39.8 & $33.2-46.7$ \\
\hline \multicolumn{12}{|c|}{ Quarantine or isolation } \\
\hline Voluntary & 28 & 11.8 & $8.1-16.9$ & 40 & $17 \cdot 3$ & 18.9 & $13 \cdot 7-25 \cdot 5$ & $3 \cdot 34$ & $2.17-5.15$ & 18.4 & $13 \cdot 5-24 \cdot 5$ \\
\hline Mandated & 80 & $25 \cdot 4$ & $20.5-31.1$ & 104 & 33.1 & 36.9 & $30.4-44.1$ & 8.68 & $\begin{array}{l}6.00- \\
12.55 \\
\end{array}$ & 42.5 & $35.4-50.0$ \\
\hline
\end{tabular}

$\mathrm{Cl}$ : confidence interval; COVID-19: coronavirus disease; ELISA: enzyme-linked immunosorbent assay; Nd: not done; OR: odds ratio; prNT: plaque reduction neutralisation tests; SARS-CoV-2: severe acute respiratory syndrome coronavirus 2.

a Not corrected for sensitivity and specificity.

${ }^{b}$ Lung or heart disease, diabetes, stroke, hypertension, immunodeficiency. 


\section{TABLE 2B}

Prevalence of SARS-CoV-2 IgG and neutralising antibodies in adults and association with sociodemographic, exposure and clinical characteristics, Kupferzell, Germany, 20 May-9 June 2020 ( $n=2,203)$

\begin{tabular}{|c|c|c|c|c|c|c|c|c|c|c|c|}
\hline & \multicolumn{3}{|c|}{$\begin{array}{l}\text { Prevalence of positive } \\
\text { results in both IgG-ELISA } \\
\text { (ratio } \geq 1.1) \text { and } \\
\text { prNT }\end{array}$} & \multicolumn{2}{|c|}{$\begin{array}{c}\text { IgG-ELISA-positive } \\
(\text { ratio } \geq 1.1)\end{array}$} & \multicolumn{2}{|c|}{$\begin{array}{l}\text { Seroprevalence: } \\
\text { prevalence of IgG } \\
\text { ratio } \geq 1.1 \\
\text { corrected for sensitivity } \\
88.3 \% \text { and specificity } \\
99.2 \%\end{array}$} & \multicolumn{2}{|c|}{$\begin{array}{l}\text { OR for being } \\
\text { IgG-seropositive } \\
\text { adjusted for age } \\
\text { group and sex }\end{array}$} & \multicolumn{2}{|c|}{$\begin{array}{l}\text { Distribution among } \\
\text { seropositives }^{\mathrm{a}} \\
(\operatorname{IgG} \text {-ELISA; } n=249)\end{array}$} \\
\hline & $\mathrm{n}$ & $\begin{array}{c}\text { Weighted } \\
\%\end{array}$ & $95 \% \mathrm{Cl}$ & $\mathrm{n}$ & $\begin{array}{l}\text { Prevalence, } \\
\text { weighted \% }\end{array}$ & $\begin{array}{c}\text { Weighted } \\
\%\end{array}$ & $95 \% \mathrm{Cl}$ & OR & $95 \% \mathrm{Cl}$ & $\begin{array}{l}\text { Weighted } \\
\%\end{array}$ & $95 \% \mathrm{Cl}$ \\
\hline \multicolumn{12}{|l|}{ Self-reported health } \\
\hline Very good & 57 & 7.7 & $5.9-10.0$ & 95 & 13.1 & 14.0 & $11.2-17.5$ & 1.41 & $1.04-1.90$ & 36.0 & $30.0-42.4$ \\
\hline Good & 92 & 8.1 & $6.5-10.1$ & 127 & 11.1 & 11.8 & $9.6-14 \cdot 3$ & 1 & Reference & 53.2 & $46.8-59.6$ \\
\hline $\begin{array}{l}\text { Moderate/bad/ } \\
\text { very bad }\end{array}$ & 15 & 6.3 & $3.8-10.2$ & 23 & 9.4 & 9.8 & $6.2-14.9$ & 0.69 & $0.42-1.14$ & 10.8 & $7.2-15.8$ \\
\hline \multicolumn{12}{|l|}{ Medical conditions } \\
\hline $\begin{array}{l}\text { Self-reported } \\
\text { COVID-19 }\end{array}$ & 34 & 71.6 & $57.8-82.3$ & 43 & 89.0 & 100.8 & $88.0-107.5$ & 81.20 & $\begin{array}{l}34.78- \\
189.55\end{array}$ & 19.2 & $14 \cdot 2-25 \cdot 4$ \\
\hline Chronic conditions $^{\mathrm{b}}$ & 53 & 8.9 & $6.7-11.7$ & 71 & 11.6 & 12.3 & $9.5-15.8$ & 0.78 & $0.55-1.10$ & 35.4 & $28.9-42.4$ \\
\hline \multicolumn{12}{|c|}{ Symptoms since 1 February } \\
\hline Fever $\geq 38^{\circ} \mathrm{C}$ & 66 & 32.7 & $26.0-40.3$ & 77 & 38.4 & 42.9 & $34.8-51.7$ & 6.82 & $4.78-9.72$ & 31.4 & $25.4-38.2$ \\
\hline $\begin{array}{l}\text { Dyspnoea, } \\
\text { shortness of } \\
\text { breath }\end{array}$ & 28 & 19.4 & $13.4-27.3$ & 36 & 25.8 & 28.5 & $20.6-38.2$ & 2.80 & $1.81-4.33$ & 14.6 & $10.5-20.1$ \\
\hline Pneumonia & \multicolumn{3}{|c|}{$\mathrm{Nd}$} & 4 & $\mathrm{Nd}$ & \multicolumn{2}{|c|}{$\mathrm{Nd}$} & \multicolumn{2}{|r|}{$\mathrm{Nd}$} & \multicolumn{2}{|c|}{$\mathrm{Nd}$} \\
\hline $\begin{array}{l}\text { Congested/running } \\
\text { nose }\end{array}$ & 74 & 11.6 & $9.0-14.8$ & 102 & 16.0 & 17.3 & $13.9-21.4$ & 1.88 & $1.39-2.56$ & 39.0 & $32.7-45.7$ \\
\hline Cough & 76 & 14.1 & $11.1-17.7$ & 101 & 18.6 & 20.4 & $16.5-25.0$ & 2.34 & $1.73-3.17$ & 39.9 & $33.5-46.7$ \\
\hline $\begin{array}{l}\text { Pain when } \\
\text { breathing }\end{array}$ & 13 & 17.0 & $10.0-27.5$ & 17 & 22.9 & $25 \cdot 3$ & $15.4-38.6$ & 2.39 & $1.31-4.36$ & 6.8 & $4.2-10.9$ \\
\hline Sore throat & 55 & 10.1 & $7.6-13.1$ & 68 & 12.5 & 13.3 & $10.2-17.2$ & 1.20 & \begin{tabular}{|l|}
$0.86-1.68$ \\
\end{tabular} & 25.7 & $20.3-31.9$ \\
\hline $\begin{array}{l}\text { Loss of smell or } \\
\text { taste }\end{array}$ & 69 & 54.9 & $45.8-63.7$ & 92 & 71.5 & 80.8 & $70.8-89.3$ & 30.49 & $\begin{array}{c}19.68- \\
47.25\end{array}$ & 36.5 & $30.2-43.3$ \\
\hline No symptoms & 24 & 2.6 & $1.7-4.0$ & 55 & 5.6 & 5.5 & $3.9-7.6$ & 1 & Reference & 24.5 & $18.9-31.1$ \\
\hline $\begin{array}{l}\text { Mild symptoms } \\
\text { only }\end{array}$ & 113 & 12.6 & $10.3-15.4$ & 152 & 16.6 & 18.1 & $15.0-21.6$ & 3.77 & $2.62-5.42$ & 59.4 & $52.4-66.1$ \\
\hline $\begin{array}{l}\text { Moderate or } \\
\text { severe symptoms } \\
\text { (pneumonia, } \\
\text { dyspnoea) }\end{array}$ & 29 & 19.2 & $13.3-26.8$ & 39 & 26.8 & 29.7 & $21.8-39.2$ & 6.30 & $3.85-10.30$ & 16.1 & $11.7-21.7$ \\
\hline
\end{tabular}

$\mathrm{Cl}$ : confidence interval; COVID-19: coronavirus disease; ELISA: enzyme-linked immunosorbent assay; Nd: not done; OR: odds ratio; prNT: plaque reduction neutralisation tests; SARS-CoV-2: severe acute respiratory syndrome coronavirus 2.

a Not corrected for sensitivity and specificity.

${ }^{b}$ Lung or heart disease, diabetes, stroke, hypertension, immunodeficiency.

Complementary categories are not always shown, e.g. 'not working with patients' and missing values not shown, therefore $\mathrm{n}$ do not always add up to the total.

the three other German studies with available data, the underascertainment ratio has been smaller than 6 $[11,13,14]$ and not 10 or higher as in a number of international locations [17]. The association of seropositivity with very good self-reported health, although not statistically significant, may be indicative of lower risk awareness and less protective behaviour. As the CoMoLo study continues in three other locations, more detailed analyses might be possible with a larger sample.
According to a recent report of IgG levels stable for up to 4 months on the one hand [18], and reports on waning of neutralising antibodies on the other hand $[10,19,20]$, we base our estimate of the cumulative incidence of infections on IgG antibodies. However, in our subsample of 50 participants with self-reported PCRbased COVID-19 diagnoses, $11 \%$ were not IgG-positive which is in line with large population-based studies from Spain and New York State [21,22]. The cumulative incidence of infection in this subgroup, which was based on IgG corrected for sensitivity and specificity, 
TABLE 3

Participants with self-reported COVID-19 diagnosis, Kupferzell, Germany, 20 May-9 June $2020(n=50)$

\begin{tabular}{|c|c|c|c|c|c|c|c|c|c|}
\hline & \multicolumn{3}{|c|}{ Total } & \multicolumn{3}{|c|}{$18-49$ years } & \multicolumn{3}{|c|}{$\geq 50$ years } \\
\hline Total (n unweighted) & \multicolumn{3}{|c|}{50} & \multicolumn{3}{|c|}{25} & \multicolumn{3}{|c|}{25} \\
\hline Mean age in years (range) & \multicolumn{3}{|c|}{$52(19-81)$} & \multicolumn{3}{|c|}{$37(19-49)$} & \multicolumn{3}{|c|}{$63(50-81)$} \\
\hline IgG-positive & 43 & 89.0 & $77.3-95.0$ & 19 & 79.1 & $58.6-91.0$ & 24 & 95.9 & $74.6-99.5$ \\
\hline $\begin{array}{l}\text { IgG-positive, corrected for sensitivity } \\
88.3 \% \text { and specificity } 99.2 \%\end{array}$ & 43 & 100.8 & $87 \cdot 4-107 \cdot 7$ & 19 & $89 \cdot 5$ & $66.0-103.1$ & 24 & 108.7 & $84 \cdot 3-112.8$ \\
\hline IgG-positive and prNT-positive & 34 & 71.6 & $57.3-82.6$ & 13 & 54.6 & $34 \cdot 3-73 \cdot 5$ & 21 & 83.5 & $62.5-93.9$ \\
\hline Chronic conditions $^{\text {b }}$ & 19 & 45.8 & $31.5-60.9$ & 6 & 29.5 & $13.2-53.6$ & 13 & $57 \cdot 7$ & $36.5-76.5$ \\
\hline No symptoms & 2 & \multicolumn{2}{|c|}{$\mathrm{Nd}$} & 2 & \multicolumn{2}{|c|}{$\mathrm{Nd}$} & 0 & \multicolumn{2}{|c|}{$\mathrm{Nd}$} \\
\hline Mild symptoms only & 31 & 61.4 & $45 \cdot 9-74.9$ & 18 & 70.6 & $47.7-86.3$ & 13 & 55.0 & $34.9-73.6$ \\
\hline $\begin{array}{l}\text { Moderate-to-severe symptoms } \\
\text { (pneumonia, dyspnoea/shortness of } \\
\text { breath) }\end{array}$ & 17 & $34 \cdot 4$ & $21.6-49.9$ & 5 & 19.2 & $7.7-40.6$ & 12 & $45 \cdot 0$ & $26.4-65.1$ \\
\hline
\end{tabular}

$\mathrm{Cl}$ : confidence interval; COVID-19: coronavirus disease; Nd: not done; OR: odds ratio; prNT: plaque reduction neutralisation tests; SARS-

CoV-2: severe acute respiratory syndrome coronavirus 2.

a Weighted \%.

${ }^{\mathrm{b}}$ Lung or heart disease, diabetes, stroke, hypertension, immunodeficiency.

There were no indeterminate IgG results. Of note, while $\mathrm{n}$ are unweighted, proportions are weighted and can therefore not be calculated from the numbers in this table.

took these seronegative infected persons almost perfectly into account. However, with increasing time lag between pandemic wave and serosurveys, some additional adjustment for seroreversion may be necessary when estimating the cumulative incidence. Of note, validation studies for serological assays should have sufficient sample sizes in the healthy group, where specificity is calculated, and in the infected group, where sensitivity is calculated. In addition, they should aim for representativeness of the target population as well as clinical outcome (mild and severe COVID19) and address cross-reactivity concerns by including subgroups of patients with other respiratory virus infections including seasonal cororavirus [23].

In Neustadt am Rennsteig, only 20 of 38 (53\%; 95\% Cl: 37-69) previously PCR-positive persons were seropositive, which may be due to a different testing strategy (whole community screening) that tested more asymptomatic cases and to the definition of seropositivity (at least two of six different antibody tests needed to be positive). Therefore, seronegative infected persons may not have been taken into account sufficiently and the underlying cumulative incidence of infections may have been as high as 8.4 per 0.52 , i.e. $16 \%$. We therefore propose that estimates of the cumulative incidence of infections should be based not only on antibody testing but also on current and past PCR test results. Within each study, the subsample of previously PCRpositive participants, i.e. participants for whom serological and virological results are available, provides valuable information for estimating the cumulative incidence of infections. It can be used to evaluate whether correction for diagnostic sensitivity, e.g. mathematical correction or combination of different immunoassays, is appropriate for the specific study.

\section{Conclusion}

This study confirmed that even in areas with high COVID-19 prevalence, only a small proportion of the population has been infected. Therefore, ongoing protective measures are justified. Moreover, this is the second German study on a community outbreak that shows that these measures are highly effective, leading at least temporarily to full containment [11].

\section{Acknowledgement}

We thank the representatives of the Hohenlohe district and the community of Kupferzell: Dr. Matthias Neth, Christoph Spieles, Silke Bartholomä and Sascha Sprenger. We thank the administrative staff and data management staff of the RKI for their support. We thank everyone who contributed to the data collection in the field: the medical staff, the hotline personnel, quality assurance, the colleagues in charge with public relations and press work and the shuttle drivers. We thank the staffs from the Central Epidemiologic Laboratory of the RKI and the Laboratory of the Center for Biological Threats and Special Pathogens (ZBS 1 ) of the RKI and the staff of the National Consultant Laboratory for Coronaviruses, Institute of Virology, of the Charité - Universitätsmedizin Berlin for their analyses. We are also grateful to all participants who took part in this study.

Funding: The study was funded by the German Federal Ministry of Health (reference number ZMVl1-2520COR402).

\section{Conflict of interest}

Dr Victor M Corman is named together with Euroimmun on a patent application filed recently regarding the diagnostic of SARS-CoV-2 by antibody testing. 


\section{Authors' contributions}

TL, CSH, MB, ASR, MS, RH, AG, JH, CK, JA, SH, HW, LHW and LS initiated the study. AHE, SB, TZ, AN, JM, OH, VMC and CD contributed to the acquisition and interpretation of data. Al authors including the CoMoLo study group members contributed to aspects of the study design. ASR and RH analysed the data and HKN wrote the first draft manuscript. All authors including the CoMoLo study group members contributed to manuscript conceptualisation, critically revised the manuscript and approved the final version.

\section{References}

1. Santos-Hövener C, Busch MA, Koschollek C, Schlaud M, Hoebel J, Hoffmann R, et al. Seroepidemiologische Studie zur Verbreitung von SARS-CoV-2 in der Bevölkerung an besonders betroffenen Orten in Deutschland - Studienprotokoll von CORONA-MONITORING lokal. Journal of Health Monitoring.2020;5(S5):2-18.

2. Corman VM, Landt O, Kaiser M, Molenkamp R, Meijer A, Chu DK, et al. Detection of 2019 novel coronavirus (2019-nCoV) by real-time RT-PCR. Euro Surveill. 2020:25(3):2000045. https:// doi.org/10.2807/1560-7917.ES.2020.25.3.2000045 PMID: 31992387

3. Wölfel R, Corman VM, Guggemos W, Seilmaier M, Zange S, Müller MA, et al. Virological assessment of hospitalized patients with COVID-2019. Nature. 2020;581(7809):465-9. https://doi.org/10.1038/s41586-020-2196-x PMID: 32235945

4. Rogan WJ, Gladen B. Estimating prevalence from the results of a screening test. Am J Epidemiol. 1978;107(1):71-6. https://doi. org/10.1093/oxfordjournals.aje.a112510 PMID: 623091

5. Oved K, Olmer L, Shemer-Avni Y, Wolf T, Supino-Rosin L, Prajgrod G, et al. Multi-center nationwide comparison of seven serology assays reveals a SARS-CoV-2 non-responding seronegative subpopulation. EClinicalMedicine. 2020;100651.

6. Ibarrondo FJ, Fulcher JA, Goodman-Meza D, Elliott J, Hofmann C, Hausner MA, et al. Rapid decay of anti-SARS-CoV-2 antibodies in persons with mild Covid-19. N Engl J Med. 2020;383(11):1085-7. https://doi.org/10.1056/NEJMc2025179 PMID: 32706954

7. Seow J, Graham C, Merrick B, Acors S, Pickering S, Steel KJA, et al. Longitudinal observation and decline of neutralizing antibody responses in the three months following SARS-CoV-2 infection in humans. Nat Microbiol. 2020;5(12):1598-607. https://doi.org/10.1038/s41564-020-00813-8 PMID: 33106674

8. Long QX, Liu BZ, Deng HJ, Wu GC, Deng K, Chen YK, et al. Antibody responses to SARS-CoV-2 in patients with COVID-19. Nat Med. 2020;26(6):845-8. https://doi.org/10.1038/s41591020-0897-1 PMID: 32350462

9. Ripperger TJ, Uhrlaub JL, Watanabe M, Wong R, Castaneda $\mathrm{Y}$, Pizzato HA, et al. Detection, prevalence, and duration of humoral responses to SARS-CoV-2 under conditions of limited population exposure. medRxiv. 2020;2020.08.14.20174490. Available from: https://www.medrxiv.org/content/10.1101/202 0.08.14.20174490v1

10. Long QX, Tang XJ, Shi QL, Li Q, Deng HJ, Yuan J, et al. Clinical and immunological assessment of asymptomatic SARSCoV-2 infections. Nat Med. 2020;26(8):1200-4. https://doi. org/10.1038/S41591-020-0965-6 PMID: 32555424

11. Weis S, Scherag A, Baier M, Kiehntopf M, Kamradt T, Kolanos S, et al. Seroprevalence of SARS-CoV-2 antibodies in an entirely PCR-sampled and quarantined community after a COVID-19 outbreak - the CoNAN study. medRxiv. 2020;2020.07.15.20154112. Available from: https://www. medrxiv.org/content/10.1101/2020.07.15.20154112V1

12. Poethko-Müller C, Prütz F, Buttmann-Schweiger N, Fiebig J, Sarganas G, Seeling S, et al. Studien zur Seroprävalenz von SARS-CoV-2 in Deutschland und international. Journal of Health Monitoring.2020;5(S4):2-16.

13. Streeck H, Schulte B, Kümmerer BM, Richter E, Höller T, Fuhrmann C, et al. Infection fatality rate of SARS-CoV2 in a super-spreading event in Germany. Nat Commun. 2020;11(1):5829. https://doi.org/10.1038/s41467-020-19509-y PMID: 33203887

14. Aziz NA, Corman VM, Echterhoff AKC, Richter A, Schmandke A, Schmidt ML, et al. Seroprevalence and correlates of SARSCoV-2 neutralizing antibodies: Results from a population-based study in Bonn, Germany. medRxiv. 2020;2020.08.24.20181206. Available from: https://www.medrxiv.org/content/10.1101/202 $0.08 .24 .20181206 \mathrm{~V} 1$

15. Knabl L, Mitra T, Kimpel J, Roessler A, Volland A, Walser A, et al. High SARS-CoV-2 Seroprevalence in Children and Adults in the Austrian Ski Resort Ischgl. medRxiv. 2020;2020.08.20.20178533. Available from: https://www. medrxiv.org/content/10.1101/2020.08.20.20178533V

16. Percivalle E, Cambiè G, Cassaniti I, Nepita EV, Maserati $R$, Ferrari $A$, et al. Prevalence of SARS-CoV-2 specific neutralising antibodies in blood donors from the Lodi Red Zone in Lombardy, Italy, as at 06 April 2020. Euro Surveill. 2020;25(24). https://doi.org/10.2807/1560-7917. ES.2020.25.24.2001031 PMID: 32583766

17. Chen X, Chen Z, Azman AS, Deng X, Chen X, Lu W, et al. Serological evidence of human infection with SARSCoV-2: a systematic review and meta-analysis. medRxiv. 2020;2020.09.11.20192773. Available from: https://www. medrxiv.org/content/10.1101/2020.09.11.20192773V2

18. Gudbjartsson DF, Norddahl GL, Melsted P, Gunnarsdottir K, Holm H, Eythorsson E, et al. Humoral Immune Response to SARS-CoV-2 in Iceland. N Engl J Med. 2020;383(18):1724-34. https://doi.org/10.1056/NEJMoa2026116 PMID: 32871063

19. Wu F, Wang A, Liu M, Wang Q, Chen J, Xia S, et al. Neutralizing antibody responses to SARS-CoV-2 in a COVID-19 recovered patient cohort and their implications. medRxiv. 2020;2020.03.30.20047365. Available from: https://www. medrxiv.org/content/10.1101/2020.03.30.20047365V2

20. Wang X, Guo X, Xin Q, Pan Y, Li J, Chu Y, et al. Neutralizing Antibodies Responses to SARS-CoV-2 in COVID-19 Inpatients and Convalescent Patients. medRxiv. 2020;2020.04.15.20065623. Available from: https://www. medrxiv.org/content/10.1101/2020.04.15.20065623V3

21. Pollán $M$, Pérez-Gómez B, Pastor-Barriuso R, Oteo J, Hernán MA, Pérez-Olmeda M, et al. , ENE-COVID Study Group. Prevalence of SARS-CoV-2 in Spain (ENE-COVID): a nationwide, population-based seroepidemiological study. Lancet. 2020;396(10250):535-44. https://doi.org/10.1016/S01406736(20)31483-5 PMID: 32645347

22. Rosenberg ES, Tesoriero JM, Rosenthal EM, Chung R, Barranco MA, Styer LM, et al. Cumulative incidence and diagnosis of SARS-CoV-2 infection in New York. Ann Epidemiol. 2020;48:2329.e4. https://doi.org/10.1016/j.annepidem.2020.06.004 PMID: 32648546

23. Houlihan CF, Beale R. The complexities of SARS-CoV-2 serology. Lancet Infect Dis. 2020;S1473-3099(20)30699-X. PMID: 32979317

\section{License, supplementary material and copyright}

This is an open-access article distributed under the terms of the Creative Commons Attribution (CC BY 4.0) Licence. You may share and adapt the material, but must give appropriate credit to the source, provide a link to the licence and indicate if changes were made.

Any supplementary material referenced in the article can be found in the online version.

This article is copyright of the authors or their affiliated institutions, 2020. 